\title{
The effect of project management through e-business and garage sales on poverty reduction
}

\author{
Mohd Sayuti Hassana, Siti Izaidah Azmi ${ }^{{ }^{*}}$, Siti Fairuz Mohd Radzia ${ }^{\mathrm{a}}$, Rahimi Che Aman ${ }^{\mathrm{b}}$, Zikri \\ Muhammad $^{c^{*}}$ and Jumadil Saputra ${ }^{\mathrm{c}}$
}

${ }^{a}$ Center for Global Sustainability Studies, Universiti Sains Malaysia, Penang, Malaysia

${ }^{b}$ Center for Co-Curricular Programme, Universiti Sains Malaysia, Penang, Malaysia

${ }^{c}$ Faculty of Business, Economics and Social Development, Universiti Malaysia Terengganu, 21030 Kuala Nerus, Terengganu, Malaysia

\section{H R O N I C L E}

Article history:

Received: February 3, 2021

Received in revised format: Octo-

ber 2, 2021

Accepted: October 31, 2021

Available online:

November 2, 2021

Keywords:

Poverty Alleviation

E-Business and Garage Sales

University Students

Sustainable Development Goal

(SDG1)

Project Management

\section{Introduction}

Poverty is the main challenge and problem faced by every society. In 1990, the global rate of people with extreme poverty was $36 \%$, and the global rate decreased to $10 \%$ in 2015 . The global rate has reduced by about $1 \%$ per year. The World Bank Group (2020) reported the global rate of people with extreme poverty decreased to $9.2 \%$ in 2017 , with less than $0.5 \%$ per year between 2015 and 2017. The progress toward ending poverty with the current global challenges, especially the pandemic of COVID-19, has raised worries about achieving the 3\% target in 2030 (Schoch, Lakner and Fleury 2020; Sumner, Hoy and Ortiz-Juarez 2020). As reported by Katayama and Wadhwa (2019), the top 5 countries listed with the highest extreme poverty rate are India, Nigeria, the Democratic Republic of Congo, Ethiopia, and Bangladesh. Nevertheless, the extreme poverty rate in two out of five countries, India and Bangladesh, was estimated to approach zero by 2030 while the other three countries had a nuanced change rate. The poverty stage could be differentiating into two types which are extreme and relative. Extreme poverty refers to a situation when a person unable to meet the basic needs of humans such as food, clothing, and shelter and when a person able to maintain the standard of living is considered relative poverty. The poverty

* Corresponding author.

E-mail address: izaidah@usm.my (S. I. Azmi)

(c) 2022 Growing Science Ltd. All rights reserved. doi: $10.5267 /$ j.jpm.2021.11.001

\begin{abstract}
Poverty is one of the significant problems, and almost all countries worldwide face poverty issues that negatively impact society. This study is written to investigate the students' knowledge and awareness of poverty and interest level in conducting e-business and garage sales. Also, ness and garage sales. There were 152 respondents from the same university who participated in this study. The data analyzed using descriptive and inferential statistics performed by SPSS23 and SmartPLS 3.3.3. The survey showed that the student's knowledge and awareness of poverty are still lacking and need improvement. Half of the respondents said they are not familiar with SDG1, and they were not aware that their university has done an event related to SDG age sales that increased their pocket money and reduced poverty rates among university students. Overall, this study's result shows a positive response from all respondents, and most of them have general ideas of poverty. In addition, this study has identified that the variable knowledge and awareness have a significant positive effect on student's intention to conduct ebusiness and garage sales.
\end{abstract}


stage for society in developed and developing countries is varying and changing over time. Most researchers stated that understanding poverty is very subjective and varies by different people's opinions and feelings (Ezeji et al., 2015; Hussain et al., 2014). Individual income, assets, competence, confidence, disempowerment, and currency rate are crucial factors that influence each individual's poverty stage. Other factors, such as knowledge, education, and skill development, also affect people's living. People with good access to knowledge, education, and skill development usually will have a good living standard, reducing the number of poverty and finally breaking the cycle of poverty among their community. Besides that, the teenagers live without their parents or guidance where they live in a hostel and campus with their financial management and some of them are struggling to manage their finances to survive their living cost. This teenager is usually the teenager who likes to further their studies after the high school stage. Some of them can manage the living cost with good financial management. Their situation changed when they came to the university as they couldn't depend too much on their parents or guidance. Due to these weaknesses, most university students face poverty during their studies at university. Nevertheless, a specific student with poor and average family background would face more difficulties during their life at university. Some of them need to look for extra income by working part-time to cover their living cost.

To help and support the student with financial difficulties, most of the governments in all countries had implemented government loans or scholarships to cover all university fees and living costs at university. Currently, students at university are also facing poverty. A student with poor and average family background would face difficulties during their study at university. They will look for financial aid and apply for government loans or scholarships to cover university payment and their university's living cost. The average monthly cost of USD 450 for a student who studies in developing countries such as Malaysia will provide a comfortable enough but still depending on living. Due to a particular area requiring high living costs especially in a city where daily expenses such as rent, and food are much more expensive than in town. Besides, accommodation type and personal lifestyle also will affect the average monthly cost. Usually, students with enough budget have less communication with the poor student, and some of them had never got in touch with the poor student. Therefore, the student's understanding and awareness of poverty need to be investigated. The students lacking sufficient average monthly cost need to survive more to sustain their living costs at university, and some of them struggle to pay for their accommodation rental. The students will look for a part-time job to solve their financial problems. In the meantime, they will face difficulties in balancing their time for education and a part-time job. Several studies were examined the impact of part-time job is lacking sufficient time for study (Manthei \& Gilmore 2005), students with full-time academic load along with part-time job are likely to suffer from stress (Jogaratnam \& Buchanan 2004), detrimental effect on the physical and mental health as well as a negative impact on students' academic performance (Carney et al., 2005). Nevertheless, the student could properly manage their time if they look for a part-time job requiring flexible time, such as e-business and garage sales. The flexibility of conducting e-business and garage sales will benefit students in time management as they could properly manage their education time. Thus, to puzzle out university students' poverty issues, a survey to determine their interest level in conducting e-business and garage sales was distributed among them. This survey is an instrument in this study that supports the researcher in observing the student's interest in helping themself to earn an extra allowance as their income generation. The findings of this study could provide beneficial information to higher education institutions, including public and private institutions and government, forecasting any programme or initiative to reduce the rate of poverty among university students. Besides that, it is also valuable for other researchers to generate a new idea or research and educator in transferring the information to their students. More importantly, this study is a step forward in eradicating poverty aligned with the global goal of SDG1.

\section{Literature review}

\subsection{Ending poverty}

Ending poverty requires more than high economic growth. Although the country has developed with a strong economy, several people trying their best to survive and maintain their standard of living are still high. A strong economy country could not promise that their people will be lifted out of poverty due to inequality. The inequality between the rich and the poor would be more apparent when the income gap is wider. The poor people will have difficulty interacting within their community and society rather than the poor people in a developing country (The World Counts 2020). Nevertheless, based on Barringer (2017), poverty could be alleviated by developing and implementing policies and programmes to sustain the increase of economic growth. It will be more efficient with the involvement of poor people to contribute to economic growth in areas such as health, education, nutrition, and sanitation. Thus, the rate of average country income will increase and reduce the rate of poverty. Besides, Mary Barringer (2017) also presents other ways in reducing poverty that was believed as effective ways in eradicating poverty by 2030 such enhance the access of rural poor to the resources by improving the management of water and other natural resources, creating and improving access to jobs and income by developing entrepreneurial talent, provides access of basic social services such as education, health care, adequate food, sanitation, shelter and clean water to all people, develops social protection system progressively to support those who could not support themselves, empowering people living in poverty by includes them together in developing and implementing of plans and programme which relates in reducing and eradicating poverty to ensure the programme will reflect them, equal access to resources and services by removing the barriers and providing access to technology and innovation such as internet and affordable energy. 
Besides that, unemployment, social exclusion, high vulnerability of certain communities to disaster or disease and other situations that prevent the communities from being productive were also composed of poverty. Therefore, the main agenda in 17 Sustainable Development Goals (SDGs), which is no poverty, has been prioritised among the other 16 SDGs, which was designed by the United Nations (UN) and agreed to adopt by all the 193 member states of the UN in September 2015 (United Nations 2020). Each SDG has several targets to be achieved accordingly in accomplishing the global goals by 2030. The UN has targeted by 2030 , and there will be at least $50 \%$ of poverty reduction by the proportion of men, women and children of all ages that live in poverty. Currently, all the involved countries will take part accordingly to ensure the success of the global goals. Poverty reduction is achievable with the high commitment and effort of everyone, and the improvement of the current initiative, technology, and tools related to pursuing the global goals and eradicating poverty. Therefore, the poverty issues must be tackled together to eradicate poverty by emphasising young people's involvement, especially those with poverty experiences, such as people with low-income family or group or community background.

Young people living in poverty are not the same group as others because they have different values, experiences and opportunities that they have faced before. Most of them face difficulties in living, such as caring for someone infected with a disease, and some are in school, but some are not. The diversity of the ability among young people is beneficial and valuable. To sustain and achieve efficient poverty reduction, strategies, ideas, supports, and young people's experiences are much more important. The contribution of young people in reducing poverty will provide more efficiency and increase the probability of making efforts that suit different young people's groups. (The national council of Swedish youth organisations 2009). Thus, university students should reveal with alleviation poverty initiative and let them be involved in tackling poverty through any programme or event or voluntary work that connects people with poverty. This will provide them with knowledge, information, experiences, and awareness of poverty to achieve the goal of SDG1.

\subsection{Poverty among students}

There are many challenges faced by children growing up in poverty. It could bring long-term obstacles such as chronic stressors and brain structure changes that will affect emotion and memory. Besides, they will face situations that cause emotional and social struggles that could affect their mental health. The mental health issues such as depression among parents and children living in poverty are commonly found in a poor community. Usually, the student who experienced emotional and social challenges shows abnormal acting behaviour during their schools, such as impatience and poor impulse control (Jensen, 2009). It is almost the same thing as happens to the student that grows in poverty since his childhood. In university life, poverty may be inconvenient to student life and make it challenging to involve their own lives fully. Their learning process at university also would be affected due to a certain degree of negative influences on their physical and mental development (Wu et al. 2020). Mark Pace (2018) stated that one out of seven students sacrificed their food to study, while one out of ten is due to disability to meet their living cost and one out of three frequently missed their class because of job commitment. Only $35 \%$ of students believe their study and job are well balanced. There are many student experiences as above and contributes to the rate of poverty among young people increasing at university - the presence of students with low-income family backgrounds existing at almost all universities. Sacrifice the source of income is normal in preparing for exams, paying rent and other commitments such as helping the family. Certain students have faced difficulties preparing food on the table, and skipping meals are normal experiences for them. The intervention of universities for students' wellbeing is needed to support their living cost at university and help them solve their financial constraint and provide them with a way to generate their source of income.

\subsection{Part-time job as an initiative to reduce poverty among students}

A part-time job is common for certain students at university. Especially for those with high commitment as students, and at the same time, they need to fulfil their responsibility to their family. These are relatively challenging for people with less experience in working. Part-time jobs are part of the student experience at their university. The concept of student's engagement as part-time employment while studying is frequently found in countries like Australia and the UK (Barron \& Anastasiadou 2009). Based on Robotham (2012), the student with a part-time job has growth. Nevertheless, certain countries do not allow their students to do a part-time job as it may disturb the student's time and focus that will affect their study performance. Most of the government is encouraging the institutions or universities not to allow them to engage with a parttime job. They need their students to keep focusing on their education time without stress. There are several negative consequences due to students' employment. It consists of less quality time in finishing their homework or assignment as a student who engages with part-time work will face difficulties to complete their homework or assignment given by the lecturer. The rate of absenteeism and less school would be higher as the student will face a constraint time for sleep, rest and study resulted lacking in preparation of education activities, the performance of the student will be lower and affecting the academic grade due to focusable during classes and the stress level of student will be high due to overload of education activities and part-time work. The potential of negative effects on the physical and mental health of students is high. However, according to Barron and Anastasiadou (2009), a part-time job could develop the student's understanding and learn practically. The knowledge and experience that they have gained during a part-time job are invaluable and priceless. For example, in terms of hospitality, they need to be friendly and polite to guests, visitors, and strangers, including serving food and drink to the guest and serving service to ensure customer satisfaction and comfort - this such a valuable experience in 
preparing them for real life. However, to involve in a part-time job by employment as an alternative income is not encouraged. The student will face a negative effect that might affect future student life, especially on mental health. Therefore, the student is encouraged to generate their pocket money and income through a part-time job by conducting e-business or garage sales. E-business is a management of business methods through IT communication such as internet application. Sending documents, exchanging data between a producer, distributor and trade partner, winning new customers, conquering markets and holding teleconferences were referred to as e-business. E-business comprises e-commerce, e-enterprise, e-economy, esociety, e-government, e-banking, e-learning (Brzozowska \& Bubel 2015). Nowadays, e-business has become increasingly popular since many generations prefer to be online transactions, online trading, online buying, and an online business. Richter et al. (2017) stated that sharing the economy online can monetise ideas and form a forward-looking business plan for monetary and non-monetary outcomes. Therefore, it can be suggested that e-business can be beneficial to the economy and society, which can improve their living standards as it is more flexible and can increase incomes and reduce poverty. Another way to improve income and reduce poverty is garage sales. In the meantime, garage sales also emphasize waste's potential to become something positive and reintegrated into the social order. Garage sales aim to give a new life to the wastes instead of ending up for disposal. The stuff is considered as waste for us, but we can retail it to somebody who is needed, thus keeping the values of the stuff and keeping them worthy. We can transform our property into second-hand trading, increasing income from our unwanted goods whilst reducing waste generation. Garage sales opportunities create benefits for waste reduction by giving up on the personal items which are usually reusable. Some of these items are offered for sale because they do not want or need the item to minimize their possessions or raise funds. In such a way, the items that are offered vastly include electronics, accessories, stationeries, books, household items and other personal belongings. Many of these consist of plastic and metal constituents, compounds of non-biodegradable constituents as waste in landfills. Via different garage sales platforms, items that are used are sold and reused by different owners. Besides receiving cheap second-hand items, it also reduces waste generation from the seller. It greatly reduces the wastes as the carbon footprint and the energy used for transporting, processing and dumping in landfills. Garage sales are complicated, economic, ecological and multi-social interaction events. It is a win-win situation because sellers pass the goods to the buyers, at which the seller can earn some extra money and save the goods from landfills while the buyers are purchasing the goods at lower prices and prolong the life of the goods. It can also help the poorer category sell their stuff to make some money or buy some lower price stuff to improve their daily life.

\section{Methodology}

\subsection{Research design}

The methods used for this study is a mixed-method approach that combines both quantitative and qualitative methods approach. The quantitative method approach was used by data collecting through a structured online questionnaire survey as well as statistical analysis in presenting a student's profile and other characteristics such as years of study, source of income and gross monthly income and expenditure and students' interest in conducting e-business and garage sales to reduce poverty.

\subsection{Participants}

A total of 152 respondents from the same university have participated in this study. The respondents comprise the population from undergraduate students with the ages between 20 to 25 years old with various years of study that included the first year to fourth or final year students. The participant's students in this study are voluntary.

\subsection{Instruments}

A questionnaire form was used to collect responses from university students. The questionnaire was designed and shared through the online application Google Forms. The link navigates to the Google Forms that were randomly sent to university students through email. They were asked to complete the questionnaire form that comprises three sections. The first section is demographic profiles such as gender, age, ethnicity, years of study, source of income and gross monthly income and expenditure. At the same time, the second part identifies the respondent's knowledge and awareness of poverty, such as understanding SDG1: No Poverty and the respondent's participation in a voluntary programme related to poverty. The third section determines their interest in conducting e-business and garage sales in generating their income at university. A completed Google Forms were received from 152 respondents of the undergraduate students from the same university with different ages and years of study. The survey information was collected by downloading the data through the online application Google Forms. After that, the data was analysed by simple descriptive statistics using Microsoft Excel.

\subsection{Data Analysis}

The data collected from the survey questionnaire are analysed using two types of statistical analysis, namely descriptive and inferential statistics. The descriptive statistics involved frequency, percentage, mean and standard deviation. Also, this study uses the figure to present the result of descriptive statistics. For inferential statistics, this study uses the structural 
equation model - partial least square (SEM-PLS). A second-generation technique is used to predict the relationship between exogenous and endogenous variables in the model. SEM-PLS consists of two main parts, namely measurement and structural model. The measurement model will report validity, reliability and discriminant validity. Besides that, the structural model will report the determination coefficient (R Square), value of predictive relevance (Q Square) and hypothesis testing.

\section{Results and discussion}

\subsection{Demographic Profile of Respondents}

Table 1 shows the demographic profile of respondents, which is section A of the questionnaire consisting of respondent information such as gender, age, ethnicity, years of study and staying place. There are a total of 152 students involved in this study. Based on the respondent characteristics, there were $74 \%$ of females and $26 \%$ of male involved in this survey. Their ages are mostly between 22 to 24 years old, where 23 years old $36 \%$ was the highest percentage followed by 22 years old with $32 \%$ and 24 years old with $19 \%$. Others were 21 years old with $7 \%$, while 20 years old and below and 25 years old and above were $3 \%$ respectively. In terms of ethnicity, most of the respondents involved are Chinese, where the percentage is $82 \%$, while the rest are Malay, India and others with respective percentages of $14 \%, 3 \%$ and $1 \%$. Other ethnicities are referred to as Orang Asli and ethnic groups from Sabah and Sarawak. Furthermore, the participants involved in this survey are staying inside campus and outside campus with a percentage of 50\% respectively. Therefore, this study involved most of the year 3 students, which is $51 \%$, followed by year 4 , year 2 and year 1 with $20 \%, 18 \%$ and $11 \%$ respectively.

Table 1

Demographic profile of respondents based on gender, age, ethnicity, years of study and staying place

\begin{tabular}{|c|c|c|}
\hline Items & & Percentage \\
\hline \multirow{2}{*}{ Gender } & Male & $26 \%$ \\
\hline & Female & $74 \%$ \\
\hline \multirow{6}{*}{ Age } & 20 and below & $3 \%$ \\
\hline & 21 & $7 \%$ \\
\hline & 22 & $32 \%$ \\
\hline & 23 & $36 \%$ \\
\hline & 24 & $19 \%$ \\
\hline & 25 and above & $3 \%$ \\
\hline \multirow{4}{*}{ Ethnicity } & Malay & $14 \%$ \\
\hline & Chinese & $82 \%$ \\
\hline & India & $3 \%$ \\
\hline & Others & $1 \%$ \\
\hline \multirow{4}{*}{ Years of Study } & Year 1 & $11 \%$ \\
\hline & Year 2 & $18 \%$ \\
\hline & Year 3 & $51 \%$ \\
\hline & Year 4 & $20 \%$ \\
\hline \multirow{2}{*}{ Staying Place } & In Campus & $50 \%$ \\
\hline & Out Campus & $50 \%$ \\
\hline
\end{tabular}

\subsection{Reponses on expenditures}

Fig. 1a shows the sources of student income to survive their life in university. Most of the respondents, 57\%, are taking loans from the government as their income source. While $27 \%$ and $13 \%$ of the respondents have received their income source from their parents and some received from scholarship and grant, respectively. The remaining $3 \%$ has received from other sources of income such as part-time work.

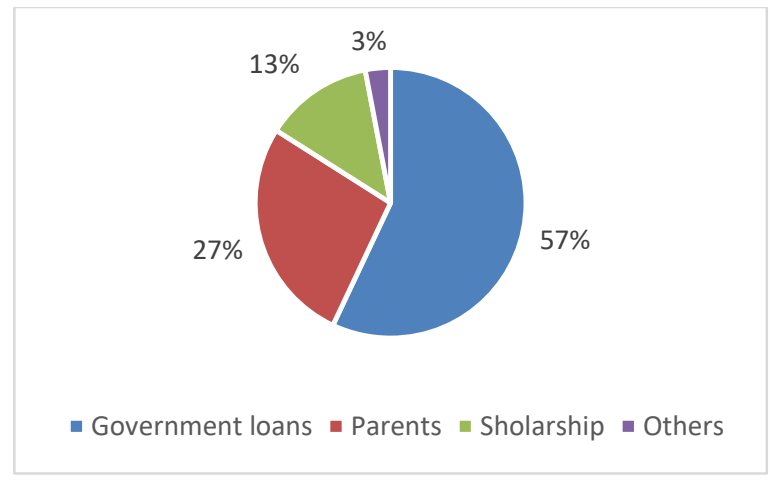

Fig. 1a. Sources of Income

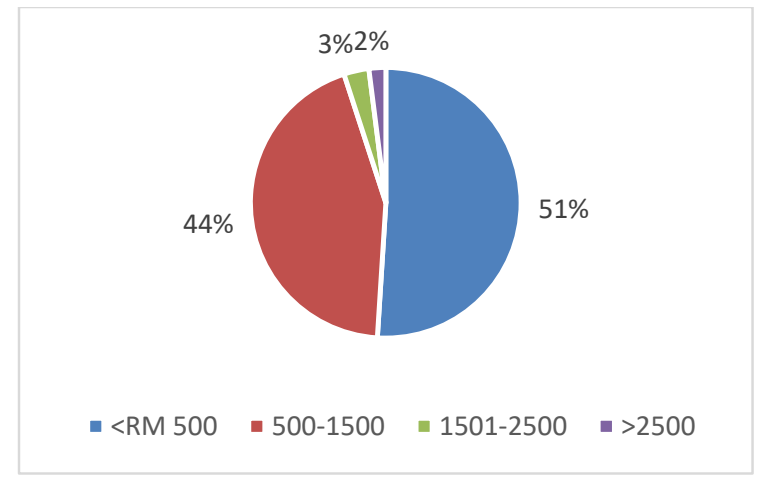

Fig. 1b. Monthly income 


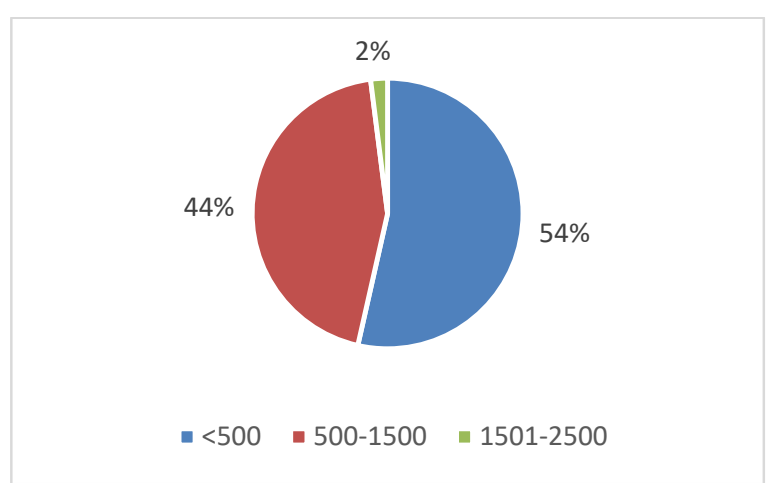

Fig. 1c. Gross monthly expenditure

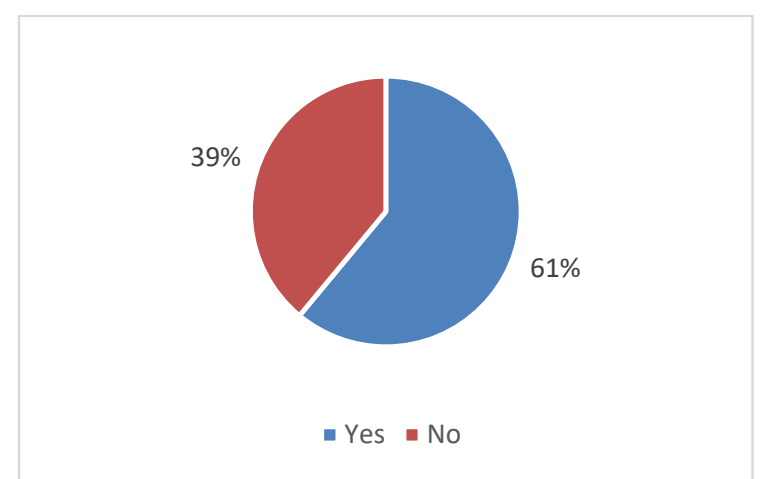

Fig. 1d. Sufficiency of income

Fig. 1. Personal information on income characteristics

The gross monthly income of the respondents is shown in Fig. 1b. Half of the respondents, $51 \%$ having a gross income of below RM 500. At the same time, 44\% of respondents have income between RM 500 to RM 1,500 and the other $3 \%$ and $2 \%$ are having income between RM 1,501 to RM 2,500 and above RM 2,500, respectively. Fig. 1c presents the gross monthly expenditure of the respondents. Most of the respondents have expanded their income below RM 500, which is 53\% and followed by respondents with monthly expenditure between RM 500 to RM 1,500, RM 1,501 to RM 2,500 and above RM 2,500 with a respective percentage of $44 \%, 3 \%$ and $1 \%$. Then, respondents were asked whether their current source of income can cover their monthly expenditure. As shown in Fig. 1d, most respondents, 61\%, have said that their current source of allowance is enough to cover their monthly expenditure. The remaining 39\%, said their current allowance couldn't cover their monthly expenditure. It indicates that university students are facing poverty and surviving their living cost at university. These students could not cover their monthly expenses due to their commitment to exam preparation, rental payment and some of them commit to helping family expenses.

\subsection{Respondents knowledge and their awareness of poverty}

Table 2 shows the respondents knowledge and their awareness of issues related to poverty. As presented in table 2, about half of the total respondents, $51 \%$, are familiar with the SDG1 goal known as No Poverty, yet the other half, with $49 \%$, are not familiar with SDG1. The respondents also have been asked about their responses to people experience in poverty could improve people's support towards poverty reduction. Based on the survey, $95 \%$ of respondents said yes to people's experiences in poverty could improve people's support towards poverty reduction, and only $5 \%$ said no to this statement. The next question is the influence of poverty on a student's daily life. Almost all respondents, who are 99\%, agreed that students' daily lives influence poverty, and only $1 \%$ disagreed with this statement. The following question is about the respondent's awareness of the university event that is related to poverty. $48 \%$ of respondents said the university had done the event related to poverty and the remaining $52 \%$ said their university hadn't done any event related to poverty. After that, the respondents were asked about their experience in any programme or voluntary work related to poverty. Most respondents, which is $87 \%$, said no, and the remaining $13 \%$ said yes.

Table 2

Respondent's knowledge and their awareness of poverty

\begin{tabular}{llc}
\hline \multicolumn{1}{c}{ Item(s) } & Response(s) & Percentage \\
\hline Familiarity with SDG1 & Yes & $51 \%$ \\
\hline $\begin{array}{l}\text { Respondents' response to people experiences in poverty could improve } \\
\text { people's support towards poverty reduction }\end{array}$ & No & $49 \%$ \\
\hline Influencing of poverty in student's daily life & No & $95 \%$ \\
& $5 \%$ & $99 \%$ \\
\hline $\begin{array}{l}\text { Respondents' response on any event related to SDG1 that has been done } \\
\text { at their university }\end{array}$ & Yes & $1 \%$ \\
\hline $\begin{array}{l}\text { Respondents experiencing in any programme or voluntary work relates to } \\
\text { poverty }\end{array}$ & Yes & $48 \%$ \\
\hline
\end{tabular}

\subsection{Respondent interest in conducting e-business and garage sales}

As presented in Table 3, most respondents have acknowledged and are aware of the existing and opportunities of e-business that are being advertised via the internet and social media. However, the remaining $39 \%$ of the respondent does not know the existence of e-business opportunities via the internet and social media. Then, the respondents also were asked about their experience in e-business. The survey result found that respondents with zero experiences in e-business are much more compared to the number of respondents with experience where the respective percentages are $79 \%$ and $21 \%$. Besides that, the respondents planning to conduct e-business also were asked. The result shows the percentage of respondents who may 
or may not plan in conducting e-business is $57 \%$ which is much higher compared to with planning and without a plan in conducting e-business where the percentages are $25 \%$ and $18 \%$ respectively. The next survey question is about respondent's opinion whether e-business is more related to a future career or only as an alternative income. Half of the respondents said e-business is more related as an alternative income while the remaining said e-business is more related to both which are future careers and alternative income (26\%), some said they do not know (16\%) and another 5\% said it is more related to career. Then, the respondents were asked to relate e-business with poverty whether e-business has played a role in reducing poverty. The result shows many respondents which $88 \%$ said yes while the rest of $13 \%$ said no.

Table 3

The respondent's interest in conducting e-business

\begin{tabular}{|c|c|c|}
\hline Items & & Number of Respondents \\
\hline Respondent's alertness on the available opportunities of e-business & Yes & $89 \%$ \\
\hline on the internet & No & $11 \%$ \\
\hline \multirow{2}{*}{ Respondent's experience in conducting e-business } & Yes & $21 \%$ \\
\hline & No & $79 \%$ \\
\hline \multirow{3}{*}{ Respondent's planning in conducting any e-business } & Yes & $25 \%$ \\
\hline & No & $18 \%$ \\
\hline & Maybe & $57 \%$ \\
\hline \multirow{4}{*}{$\begin{array}{l}\text { Respondent's thinking if e-business related to a future career or as an } \\
\text { alternative income }\end{array}$} & More related to future career & $5 \%$ \\
\hline & More related to alternative income & $53 \%$ \\
\hline & Related to both & $26 \%$ \\
\hline & Do not know & $16 \%$ \\
\hline \multirow{2}{*}{$\begin{array}{l}\text { Respondent's thinking whether e-business play a role in poverty re- } \\
\text { duction }\end{array}$} & Yes & $88 \%$ \\
\hline & No & $13 \%$ \\
\hline
\end{tabular}

Then, respondents also were asked where they acknowledge the opportunities of e-business. According to Fig., majority of respondents said they acknowledge the opportunities of e-business through the internet and social media where the percentage was $93 \%$ and followed by friends and colleagues with $63 \%$, school, college, and university with $31 \%$, TV and radio and family members and neighbourhood with $15 \%$ respectively and newspaper with the lowest percentage of $13 \%$. Table 4 indicates the survey result of the respondent's interest in conducting garage sales. Six questions have been asked to respondents in this section. This section covers the interest of respondents in conducting garage sales. The survey was beginning with the respondent's familiarity with garage sales. As shown in Table 4, the respondents were asked whether they have heard of garage sales before and $72 \%$ of respondents have responses yes to this question while the rest of $28 \%$ haven't heard about garage sales. Then, the respondents were asked whether they have ever participated in garage sales and $64 \%$ of respondents said yes. The other $36 \%$ haven't participated in garage sales. After that, the respondents were asked about their interest in participating in university garage sales. Most of the respondents which are $85 \%$ said they want to participate in garage sales and the remaining which are $10 \%$ and $5 \%$ of respondents don't have an interest and some of them said maybe will participate in garage sales. The next question is whether conducting and participating in garage sales could help in reducing poverty and most of them, which is $86 \%$, have said yes while the other $14 \%$ said no.

Table 4

Respondents interest in conducting garage sales

\begin{tabular}{|c|c|c|}
\hline $\operatorname{Item}(\mathrm{s})$ & Response(s) & Percentage \\
\hline \multirow[t]{2}{*}{ Have you heard of garage sales before? } & Yes & $72 \%$ \\
\hline & No & $28 \%$ \\
\hline \multirow[t]{2}{*}{ Have you ever participated in garage sales? } & Yes & $64 \%$ \\
\hline & No & $36 \%$ \\
\hline \multirow{3}{*}{ Are you interested in participating in the university garage sales to make money? } & Yes & $85 \%$ \\
\hline & No & $10 \%$ \\
\hline & Maybe & $5 \%$ \\
\hline \multirow[t]{2}{*}{ Do the garage sales that you are participating in help in reducing poverty? } & Yes & $86 \%$ \\
\hline & No & $14 \%$ \\
\hline
\end{tabular}

Fig. 2a indicates the respondent's response to "What items would you sell?". Most of the respondents prefer second-hand clothes and books as their items to sell compared to jewellery, shoes, and handbags where the respective percentages of agreed respondents are $63 \%, 65 \%, 18 \%$ and $34 \%$. Then, the respondents were asked to respond to "Why do people plan to have garage sales in university?". There are four reasons given in the questionnaire to choose such as to earn extra money, have a good practice (reuse), awareness to spend smartly and a platform to start a business. As shown in Figure $2 \mathrm{~b}$, most of the respondents choose to earn extra money as the main reason, followed by having a good practice (reuse), a platform to start a business and awareness to spend smartly with respective agreed percentages of $85 \%, 64 \%, 60 \%$ and $38 \%$. Overall, the result indicates that most students have acknowledged the opportunities of e-business and garage sales that could help in reducing poverty and increase their income generation as well as cover their expenditure at university. The results also showed that most students have an interest in conducting e-business and garage sales. The students do have a plan in conducting e-business and garage sales as their alternative income. Based on the survey, many students said that poverty does 
influence student's daily life in learning to manage money properly to overcome poverty, namely during financial constraints. This indicates students are aware of poverty and understand the aims of conducting e-business and garage sales that could reduce poverty among students at university.

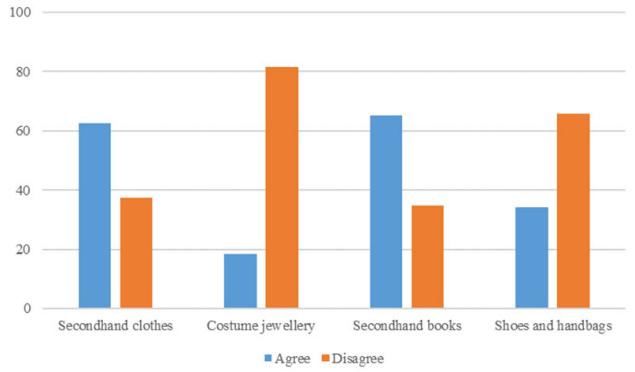

Fig. 2a. Respondents' responses on "What items would you sell?"

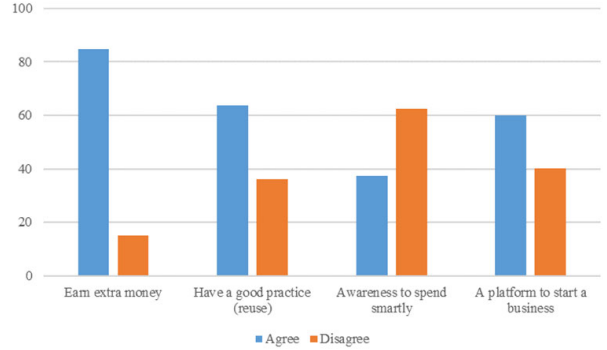

Fig. 2b. Respondents' responses on

"Why do people plan to have garage sales in university?"

\subsection{Relationship of Knowledge and Awareness of Poverty on E-business and Garage Sales}

This section reports the result of the analysis using Structural Equation Modeling that applies Partial Least Square (SEMPLS). In nature, this model has two important parts, namely measurement and structural model.

\subsubsection{Measurement model}

In this section, we report the results of the instruments validity and reliability measurement scale. The instruments are categorised as valid when the value of the loading factor is higher and equal to 0.50 . Next, the reliability of the measurement scale is Cronbach Alpha, rho_A and Composite Reliability. The threshold for these tests is higher and equal to 0.60 and 0.70 (Ramayah et al., 2018). Then, we can conclude the variables are valid and reliable. In addition, we test convergence validity to ensure the variables are convergent; this study uses Average Variance Extracted (AVE). The variable categorised as convergence when the value of AVE is higher and equal to 0.50 (Hair et al., 2014)

\section{Table 5}

Results of Instruments Validity and Reliability Measurement Scale

\begin{tabular}{|c|c|c|c|c|c|}
\hline Variable(s) & Loading(s) & Cronbach's Alpha & rho A & Composite Reliability & Average Variance Extracted (AVE) \\
\hline \multirow{8}{*}{ Knowledge } & 0.587 & \multirow{8}{*}{0.862} & \multirow{8}{*}{0.877} & \multirow{8}{*}{0.893} & \multirow{8}{*}{0.514} \\
\hline & 0.717 & & & & \\
\hline & 0.806 & & & & \\
\hline & 0.697 & & & & \\
\hline & 0.824 & & & & \\
\hline & 0.808 & & & & \\
\hline & 0.643 & & & & \\
\hline & 0.609 & & & & \\
\hline \multirow{5}{*}{ Awareness } & 0.679 & \multirow{5}{*}{0.855} & \multirow{5}{*}{0.875} & \multirow{5}{*}{0.897} & \multirow{5}{*}{0.636} \\
\hline & 0.814 & & & & \\
\hline & 0.896 & & & & \\
\hline & 0.779 & & & & \\
\hline & 0.804 & & & & \\
\hline \multirow{6}{*}{$\begin{array}{l}\text { Intention to E- } \\
\text { Business and } \\
\text { Garage Sales }\end{array}$} & 0.772 & \multirow{6}{*}{0.876} & \multirow{6}{*}{0.890} & \multirow{6}{*}{0.907} & \multirow{6}{*}{0.620} \\
\hline & 0.828 & & & & \\
\hline & 0.857 & & & & \\
\hline & 0.683 & & & & \\
\hline & 0.848 & & & & \\
\hline & 0.719 & & & & \\
\hline
\end{tabular}

Table 5 shows results of instruments validity and relibility measurement scale. There are three variables involved, namely Knowledge, Awareness and Intention to E-Business and Garage Sales. The results of loadings factor are ranged 0.60 to 0.90. The minimum value of loading is 0.587 and maximum is 0.896 . The reliability value of Cronbach's Alpha, rho_A and Composite Reliability are higher than 0.60 and less than 0.90 . The value of Average Variance Extracted (AVE) is higher than 0.50 . Thus, we conclude the variables that involved are valid, reliable, and convergent. Further, this study performs the discriminant validity test. There are three types of discriminant validity, namely cross loading, Fornell-Larcker Criterion and Heterotrait-Monotrait Ratio (HTMT). Of these, we use HTMT to measure discriminant validity because of this test is more robust than two others. The value of HTMT should be less and equal to 0.85 (Ramayah et al., 2018 and Hair et al., 2017). 
Table 6

Results the Discriminant Validity using Heterotrait-Monotrait Ratio (HTMT)

\begin{tabular}{cccc}
\hline No & Variable(s) & 1 & 2 \\
\hline 1 & Awareness & & \\
2 & Intention to E-Business and Garage Sales & 0.7612 & \\
3 & Knowledge & 0.5701 & 0.8355 \\
\hline
\end{tabular}

Table 6 displays the results of discriminant validity using Heterotrait-Monotrait Ratio (HTMT). The results indicated that the value of HTMT for three variables involved are less than 0.85. It means that the variables that are used in this study are fulfilling the discriminant validity. Further, in the next section, we report the result of the structural model.

\subsubsection{Structural model}

In this section, we report the result of coefficient determination and predictive relevance and hypothesis testing. Table 7 indicates that variable knowledge and awareness explain its relationship to Intention to E-Business and Garage Sales is 0.672 or 67.2 percent. Remaining as much as 32.8 percent is explained by other variables, which are not included in this study. Also, the value of predictive relevance is 0.387 . It higher than 0 and less than 1 , it means the variables have no include omitted variable (Hair et al., 2014).

Table 7

Results the coefficient determination and predictive relevance

\begin{tabular}{ccc} 
Variable & R Square & R Square Adjusted \\
\hline Intention to E-Business and Garage Sales & 0.672 & Q Square \\
\hline
\end{tabular}

Furthermore, we report the result of hypothesis testing. Using the bootstrapping approach, this study found that the variable of knowledge and awareness have a significant positive relationship on students' intention to conduct E-Business and Garage Sales. In details, the result as seen in Table 8 .

Table 8

Results the Hypothesis testing

\begin{tabular}{|c|c|c|c|c|c|c|c|}
\hline \multirow{2}{*}{ Path Analysis } & \multirow{2}{*}{$\begin{array}{c}\text { Original } \\
\text { Sample }(\mathrm{O})\end{array}$} & \multirow{2}{*}{$\begin{array}{c}\text { Sample Mean } \\
\text { (M) }\end{array}$} & \multirow{2}{*}{$\begin{array}{l}\text { Standard } \\
\text { Deviation } \\
\text { (STDEV) }\end{array}$} & \multicolumn{2}{|c|}{ Confidence Intervals } & \multirow{2}{*}{$\begin{array}{l}\text { T Statistics } \\
(|\mathrm{O} / \mathrm{STDEV}|)\end{array}$} & \multirow[t]{2}{*}{ P Values } \\
\hline & & & & $2.5 \%$ & $97.5 \%$ & & \\
\hline $\begin{array}{c}\text { Awareness } \rightarrow \text { Intention to } \\
\text { E-Business and Garage } \\
\text { Sales }\end{array}$ & 0.394 & 0.397 & 0.075 & 0.256 & 0.542 & 5.284 & 0.000 \\
\hline $\begin{array}{c}\text { Knowledge } \rightarrow \text { Intention to } \\
\text { E-Business and Garage } \\
\text { Sales }\end{array}$ & 0.546 & 0.542 & 0.072 & 0.403 & 0.666 & 7.592 & 0.000 \\
\hline
\end{tabular}

Table 8 captures the results of hypothesis testing. The value of regression coefficient of awareness is 0.394 , standard deviation is 0.075 , C.I $2.5=0.256$ and C.I. $97.5=0.542$, t-stat is 5.284 and significant at the level 0.01 ( 1 percent). It means that by assuming an increase in the students' awareness by 1 percent, it would give effect on the intention to conduct ebusiness and garage sales at 39.4 percent. Also, knowledge regression coefficient is 0.546 , standard deviation is 0.072 , C.I $2.5=0.403$ and C.I. $97.5=0.666$, t-stat is 7.592 and significant at the level 0.01 ( 1 percent). It means that by assuming an increase of the students' knowledge by 1 percent, it would give effect on the intention to conduct e-business and garage sales is 54.6 percent (See Fig. 4).

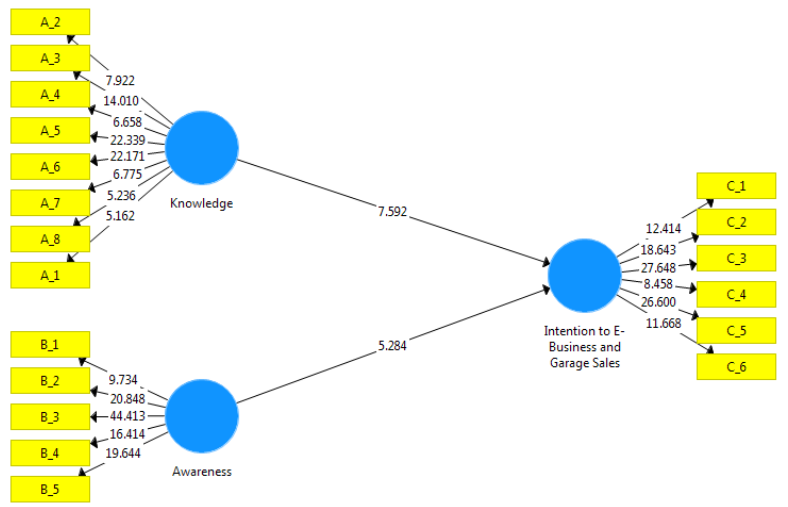

Fig. 4. The result of hypothesis testing using PLS Bootstrapping 


\section{Conclusion}

In project management, creating productive employment opportunities is essential for achieving poverty alleviation, sustainable economic and social development. It is crucial to provide decent job opportunities and businesses that secure income and empowerment for the poor. Economic growth can be stimulated such as bringing a high rate of expansion of productive and remunerative employment, which can lead to a reduction in poverty. It has been known that SDG1 consists of a few main targets where the first target is to eradicate extreme poverty. Secondly, it is to reduce poverty by at least $50 \%$. Moreover, SDG 1 targets are to implement social protection systems in which the population is covered by social insurance programs and is to give equal rights to ownership, basic service, technology, and economic resources. Lastly, the target is to build resilience to environmental, economic, and social disasters. The education on poverty and SDG1 needs to be revealed to all university students and involve the students in a programme or event related to poverty and SDG1. It will ensure the students have gained enough knowledge, information, experiences, and awareness to reduce poverty and achieve the SDG1 goal. Even though SDG1 and poverty reduction were the main global targets, more students still did not know about SDG1 and poverty. The survey shows about half of the students are not familiar with the meaning of SDG1. They could not relate the poverty, SDG1 and university events related to poverty and SDG1. Therefore, creating or conducting events to educate them and increase their awareness of poverty. More programs and voluntary work among students to help the poor is a valuable experience that can enhance the awareness level among students. Carefully and comprehensively designed and targeted will eradicate poverty in the future. Awareness has the advantage of ensuring that poverty reduction becomes a collective responsibility and not that of just the government or a single agency entrusted with the task of eradicating poverty. Besides, most of the students are aware of e-business and garage sales opportunities as their sources of making money but very least engaged in e-business and garage sales. However, the students believe that e-business and garage sales can play a role in alleviating poverty as they can earn some money and increase their sources of income. Moreover, instead of poverty reduction, the garage sales opportunity is also a solution for waste reduction that gives many benefits to the environment. Therefore, the university should guide them in creating their business through online and garage sales to help students facing poverty solve their financial constraints. Furthermore, by having an awareness of poverty, students have learned how to spend money and manage their business well. Eventually, students will be able to start a business successfully and contribute more job opportunities to the public and reduce poverty and achieve the SDG1 targets.

In conclusion, conducting project management through e-business and garage sales at university is the solution to poverty alleviation that can help many students survive their living cost at university. Business and job opportunities at university are important for students. Students facing poverty issues will have opportunities to be involved in both businesses to earn more money and reduce parents' burden. Awareness of poverty could remind students to learn ways to manage money wisely and manage their business well. Eventually, students will be able to start a business successfully and contribute more job opportunities to the public and reduce the rate of poverty issues faced outside the university. In addition, this study has identified that the variable knowledge and awareness have a significant positive effect on student's intention to conduct ebusiness and garage sales.

\section{Acknowledgement}

The authors would like to thank FRGS Grant, Ministry of Higher Education Malaysia (Research Title: Developing a MultiFunctionality Model of Agropreneurship towards SDGs 2030 for Economic, Social \& Environment Growth - Project Code: 6711739) for financial support. Authors are also grateful to the anonymous reviewers for their insightful suggestions and careful reading of the manuscript. The author also would like to thank the group of WSU101 Course - Sustainability: Issues, Challenges \& Prospects for allowing the author to come out with this research paper. They are: Chua Seong Jinq, 137577; Darren Jong Jin Hao, 137578; Devananthini A/P Gopalakrishnan, 137579; Jessica Khoo Siok Lin, 137587; Lai Yuen Sze, 137593; Nishalini A/P Ratha Pukallenthy, 137621; Nyew Sock Fei, 137660; Sujatha A/P Subramaniam, 140064; Sung Yan Ying, 137678; Yeoh Choonwhoei, 137691.

\section{References}

Barringer, M. (2017). 10 Ways to Reduce Poverty in The World. https://borgenproject.org/10-ways-to-reduce-poverty-inthe-world/ (accessed 2 September 2020)

Barron, P., \& Anastasiadou, C. (2009). Student part-time employment: Implications, challenges and opportunities for higher education. International Journal of Contemporary Hospitality Management, 21(2), $140-153$. https://doi.org/10.1108/09596110910935642

Brzozowska, A., \& Bubel, D. (2015). E-business as a New Trend in the Economy. Procedia Computer Science, 65(Iccmit), 1095-1104. https://doi.org/10.1016/j.procs.2015.09.043

Carney, C., McNeish, S. \& McColl, J. (2005). The impact of part-time employment on students' health and academic performance: a Scottish perspective. Journal of Further and Higher Education, 29(4), 307-319.

Ezeji, H. A., Ugwoke, E. O., Edeh, N. I., \& Okanazu, O. O. (2015). Business Education: A Tool for Poverty Alleviation in Enugu State. American Journal of Industrial and Business Management, 05(09), 601-609. https://doi.org/10.4236/ajibm.2015.59060. 
Hair Jr, J. F., Sarstedt, M., Hopkins, L., \& Kuppelwieser, V. G. (2014). Partial least squares structural equation modeling (PLS-SEM): An emerging tool in business research. European business review.

Hair Jr, J. F., Sarstedt, M., Ringle, C. M., \& Gudergan, S. P. (2017). Advanced issues in partial least squares structural equation modeling. saGe publications.

Hussain, M. D., Bhuiyan, A. B., \& Bakar, R. (2014). Entrepreneurship Development and Poverty Alleviation: An Empirical Review Journal of Asian Scientific Research. In Journal of Asian Scientific Research (Vol. 4, Issue 10). http://www.aessweb.com/journals/5003

Jensen, E. (2009). Teaching with poverty in mind. Alexandria, VA: ASCD.

Jogaratnam, G., \& Buchanan, P. (2004). Balancing the demands of school and work: stress and employed hospitality students. International Journal of Contemporary Hospitality Management 16(4) pp237-245.

Katayama, R., \& Wadhwa, D. (2019). Half of the world poor live in just 5 countries. World Bank Blogs. https://blogs.worldbank.org/opendata/half-world-s-poor-live-just-5-countries (accessed 13 August 2020).

Manthei, R. \& Gilmore, A. (2005). The effect of paid employment on university students' lives. Education and Training, 47(3), 202-215.

Mark Pace. (2018). What it's like to be a student on the poverty line. University World News. https://www.universityworldnews.com/post.php?story $=20181018090002320$ (accessed 13 August 2020)

Ramayah, T., Cheah, J., Chuah, F., Ting, H., \& Memon, M. A. (2018). Partial least squares structural equation modeling (PLS-SEM) using smartPLS 3.0.

Richter, C., Kraus, S., Brem, A., Durst, S., \& Giselbrecht, C. (2017). Digital entrepreneurship: Innovative business models for the sharing economy. Creativity and Innovation Management, 26(3), 300-310.

Robotham, D. (2012). Student part-time employment: Characteristics and consequences. Education and Training, 54(1), 65-75. https://doi.org/10.1108/00400911211198904

Schoch, M., Lakner, C. and Fleury, M. (2020). Progress toward ending poverty has slowed. World Bank Blogs. https://blogs.worldbank.org/opendata/progress-toward-ending-poverty-has-slowed (accessed 27 October 2020)

Sumner, A., Hoy, C., \& Ortiz-Juarez, E. (2020). Estimates of the impact of COVID-19 on global poverty. Unuwider, April, 1-9. https://doi.org/10.35188/UNU-WIDER/2020/800-9

The national council of Swedish youth organisations (2009). The Role of Young People in Poverty Reduction. 1-32. www.lsu.se

The World Bank Group. (2020). Measuring Poverty. https://www.worldbank.org/en/topic/measuringpoverty (accessed 13 August 2020).

The World Counts. (2020). What's it like to be really poor? https://www.theworldcounts.com/stories/poverty-in-the-worldtoday (accessed 26 August 2020).

United Nations. (2019). No Poverty and Zero Hunger. https://www.un.org/sustainabledevelopment/goal-of-the-month-archive/goal-of-the-month-october-2019/ (accessed 13 August 2020).

United Nations. (2020). The Sustainable Development Agenda. https:/www.un.org/sustainabledevelopment/developmentagenda/ (accessed 1 September 2020).

Wu, F., Zheng, Q., Tian, F., Suo, Z., Zhou, Y., Chao, K. M., Xu, M., Shah, N., Liu, J., \& Li, F. (2020). Supporting povertystricken college students in smart campus. Future Generation Computer Systems, 111, 599-616. https://doi.org/10.1016/j.future.2019.09.017 
(C) 2022 by the authors; licensee Growing Science, Canada. This is an open access article distributed under the terms and conditions of the Creative Commons Attribution (CC-BY) license (http://creativecommons.org/licenses/by/4.0/). 